\title{
Mythology and Politics - The Case of Kosovo
}

\section{Tatjana Đurišić Bečanović}

Faculty of Philology, University of Montenegro

\section{Abstract}

This article deals with a specific semiotic connection established between mythology and politics that can be helpful in terms of explaining and understanding a very complex semiotization of Kosovo in South Slavic cultures. The author analyzes a poetic definition of Kosovo offered by Matija Bećković - "Kosovo is the most expensive Serbian word", because in politics, just like in mythology, everything is about words and their meaning, and not about facts.

Keywords: mythology of Kosovo, semiotics, symbolic sign, defense, political solution, (post)colonial discourse, inferior culture, colonial trauma, auto communication

\section{Introduction}

\section{Constructed sacredness}

The abuse of Kosovo is very common in public discourse, especially in the South Slavic cultures and it almost always signifies a sacred place and memory unit that hurts every Christian heart and calling for revenge. This sacredness has been constructed with the great help of political centers of power, that are using Kosovo for centuries as a sign of Christian identity and strong resistance to the Turkish colonial power (Said, 1978) but also as a very forceful instrument of encouraging the hatred towards Alterity, especially Muslims. In $19^{\text {th }}$ and $20^{\text {th }}$ century, under the influence of political elite, Kosovo was transformed into a very powerful political weapon, always used when it's needed to call common people to die for the homeland due to the idea that the military defeat of Serbian, and, above all, Christian army in the Battle of Kosovo should be understood as a moral victory.

Ivan Čolović described the political abuse of Kosovo in his book entitled The Death on Kosovo Field and he used the syntagm Kosovo myth, with a strong attempt to demystify it. We believe that it would be more appropriate to use the syntagm Kosovo mythology because there is more than one story involved in this process of mythologisation, and by definition the myth is just one story though mythology is a dense network of stories that are forming the semantic, axiological and semiotic system, which happens in the case of Kosovo. 
There are numerous authors who have written about Kosovo as a mythological phenomenon in scientific discourse (Čajkanović, 1973; Đorđević, 1984; Ćirković, 1990; Dejzings, (2005); Di Lelio, 2010) and Miodrag Popović (2007) came to a conclusion that in $19^{\text {th }}$ century Kosovo and Vidovdan became the symbol of bloody revenge on everything that is Turkish or Muslim. On the other hand, the poets and the priests (Velimirović, 2013) mainly supported the political abuse of this phenomenon and contributed to the process of its mystification, which further strengthening could be very dangerous in unstable political situation in Balkans.

Demystification and deconstruction are the most dangerous processes that are not desirable in the political narration of Kosovo, because the political elite and Serbian Orthodox Church need this captivating effect on the crowd that Kosovo mythology still possesses. Therefore, it would be very important to analyze and to explain this specific semiotic phenomenon and to warn about its fatal influence when it's interpreted or considered as a doubtless historical truth.

\section{Case Study: A spectre is haunting Balkans - the spectre of Kosovo}

\section{Aim and Objectives}

Aim of this paper is to prove that nowadays Kosovo is a very dangerous and powerfull semiotic product, which is ticking in South Slavic semiosphere like a special semiotic dynamite. There is no artistic code in South Slavic, espacialy Serbian culture in which Kosovo does not exist as a very powerful simbolic sign that has become sacred in a special semiotic process which took place in Balkans semiosphere in the last six centuries, after the Battle of Kosovo (28 th June 1389).

\section{Methodology}

There are three disciplines in semiotics that make the famous semiotic triangle: syntax, semantics and pragmatics. Semiotic process that leads to establishing of a sacred sign occurs in the area of semiotic pragmatics when the interlocutor develops a very emotional attitude towards the particular sign, so he is ready to sacrifice his own life or to kill for its sacredness, which always gives specific status and functions to those signs in every culture. But, the pragmatic relation of a sign is the youngest, the most complex and least examined discipline of semiotics (Oraić Tolić, 1990).

In this pragmatic aspect of signs there is a great deal of manipulative potential that could be used in public, especially political discourse with an evil intent, to develop a social tension and anxiety, panic or fear. Cults have also been built in pragmatics and they lead to intense semiotization of sacred signs, which structure has become very complex, as a result of the process of intertextuality, and very influential in the social semiotics because it has set codes of behavior, conducts ideological patterns and forms the public opinion. Cults are very complex semiotic products which were created when sacred signs were submitted to additional semiotization during the ritual that involves a significant number of people and a great deal of social influence. 
In this process of building a cult, the verse and its mnemonic functions play a very important role, so the poetry of the greatest Montenegrin poet Petar II Petrović Njegoš is included in this procedure of intense semiotization, as it has always played a very important role in shaping of Kosovo mythology.

\section{Discussion}

Kosovo mythology was created in South Slavic oral and written (post)colonial discourse, in which the ethically most correct picture of the world is clearly located within the Christian, rather Orthodox, colonized and inferior culture. Under the influence of (post)colonial situation and this social and cultural trauma stored deeply in collective memory, Kosovo mythology acts as a trigger of different defensive mechanisms of the domicile, Christian culture:

"The man has developed defence techniques in an amazingly clever way, not only in the field of the war circumstance but also in the field of religion, medicine and legal coercion. He must defend himself not only against potential hostile forces of nature but also against those in the human society.

Moreover, he also has to cope with the destructive forces in his personality. The aim of a religion is to eliminate the hazards that exist in nature, as well as those that are present in an individual. Law enforcement institutions were created to deal with social offenders, while an armed force is used against other communities. Medicine, in turn, protects the group or individual from a disease". (Hol 1976: 58).

That's why defense is a very powerful cultural mechanism which in every historical and political situation provides ethically correct position for defenders of homeland and domicile culture, national identity, dominant religion and image of God, so they are constructed in common mind as martyrs and knights in shining armor, and therefore they have a very wide influence on the crowd and its imaginarium.

Just like religion, medicine and legal coercion, the texts produced in a given semiosphere (Lotman 2004) function as a very important defense mechanisms of a culture because of the fact that their mnemonic function is crucial in preserving the identity of a socio-cultural community, which is particularly at risk in terms of the colonial situation. In such conditions the activity of religious codes as the strongest defense mechanisms increases, whose texts have emphasized pragmatic value because they are usually written to express sacredness and are rooted deeply in the phylogenetic memory, so they are the main carriers of resistance to colonial powers and all forms of cultural and identity violence.

We can recognize three areas in which semiotization of Kosovo took place:

1. Semiotization in oral codes, in the system of epic songs with the Kosovo cycle in its center. (This process is over);

2. Semiotization in artistic codes - poetry, painting, cimenatography, sculpture, music, pop and rap culture. (This process is still in progress); 


\section{Semiotization in political discourse. (Still in progress).}

So, while offering a political solution, it is very important to bear in mind that we are not dealing just with a geopolitical phenomenon but with a first grade mythological phenomenon, because Kosovo is the most rigid and complex sign of Christian orthodox identity in the South Slavic (post)colonial discourse.

In this subtle semiotic way Kosovo is remembered and stored in the collective memory as a sacred sign, trapped in a malicious mythological net, with a great dill of transcendental meaning in its semantic field, so it can't be treated as any other place or geographic point in political discourse or practice. It's a very emotional and expressive sign for every member of South Slavic interpretative community. For example, the strength of Serbian identity narration is primarily based on Kosovo mythology, that was built for centuries and remembered in collective memory as a severe trauma with precise time and spacial coordinates, which made it very powerful in the field of social semiotics because it relied on doubtless hystorical "truth". So, in South Slavic, especially Serbian culture an intense process of semiotization of Kosovo took place, while this chronotope (Bahtin, 1989), within artistic codes and strategies, is transformed into a powerful simbol of identity:

"Geography is easily transformed into the symbols. It's especially noticeable when some geographical point becomes a place of permanent war operations, national or religious collision, or it's just differently recognized and valorized in the confronted national traditions." (Lotman 2004: 270).

Editional semiotization of Kosovo started in oral codes and during the further inter textual communication there's been formed a very complex symbolic sign that was curved deeply into the philogenetic memory. Therefore, the phrase - Kosovo is the most expensive Serbian word - is a very powerful clero-poetic product of that holly semiotization, which is awaking all dead martyrs and calling for defensive reaction by two serious authorities: one of the author, famous Serbian poet - Matija Bećković, and the other of the publisher - Serbian Orthodox Church, which already had a very wide influence on common people. Since religious texts and Church editions are keeping and caring on information of great importance for the community, in rough polemics of identity, the authority of ecclesial chiefs influenced the information so that no data is neutral in the ethic way, because the authority of the speaker or, in this case, publisher provides this special ethic value to the information.

Nationalists and the Church, the main keepers of the collective identity, are going to be very emotional and irrational in this Kosovo matter, and therefore very aggressive in every political situation. However, they're just like the opium for the crowd, so everything they're rolling on their seductive tongue is very dangerous in a rough political way. The characteristics of nationalists' discourse, which is always in a very aggressive dialogue towards the other identity patterns, are: playing with the strong collective traumas and, at the same time, with emotions of a recipient, afirmative kind 
of intertextuality towards sacred texts (Bible or Qur'an), which includes the abuse of sacred signs, and intense autocommuniction with a fatal consequences that lead to a cultural authisam.

Nationalism, as a dominant ideological paradigm in Balkans today, and religious codes are endangering intercultural dialogue, with a rather retrograde and, unfortunately, very wide influence they aim to alienate not to connect. Nationalism, mainly based on mythological way of thinking, promotes aggressive strategies of communication, limiting free thinking and encouraging aggressiveness towards Alterity, so it's very dangerous ideological platform, and its further strengthening could be fatal considering Balkans cultural and religious dissimilarities that have deep hystorical foundation.

The most important religious dissimilarity in Balkans and in South Slavic cultures is the one between Christianity and Islam, as a consequence of historical events and colonial situation, which already had a fatal epilog in war in Bosnia. History shows that military operations in this area are accompanied by bloodshed between people of diferent religious identity, especially between Christians and Muslims. So, we can conclude that this religious dissimilarity will be always the source of aggressiveness on all levels of culture and it shouldn't be encouraged in public discourse, particularly not in political one. This religious dissimilarity is really calling for non-aggressive way of thinking, cooperative starategies of communication and positive semiotization and consideration of Alterity, especially after the latest refugee crisis in Europe, because the antiislamic mood is going to rise and it could be very dangers for Balkans.

In Balkans we are dealing with mythological human being suffering from postcolonial trauma that is especially reflected on narration of identity where Kosovo, as a very complex semiotic product, plays the main role because it splits history of Balkans in two parts functioning as a special temporal and semiotic border. Thus, temporal and spacial units appear as bearers of additional meaning because, in the view of anthropologists, time and space have ability to speak (Hol 1976), which results in increased semiotization of temporal units going beyond their primary function of an instrument for measuring time. The same semiotic process overtakes the spacial codes, so they can transfer non-spacial information as well, such as ideological, axiological or cultural one. Those semiotic procedures transformed Kosovo into a specific cultural border that splits the time on a period before the Ottoman invasion and colonization, and a period after that significant cultural impact with numerous very serious and painful consequences.

Lotman's observation that the organic connection between culture and communication is one of the basic principles of modern culturology (Lotman 2004: 28) may help in the interpretation of the particular communication established between the colonial power and colonized culture, which includes the modification of cultural codes as a necessary consequence of the colonial dialogue. In addition, the interpretation of culture as a form of communication has been advocated by some 
important anthropologists, whose cultural theory relied upon the linguistic models (Hol 1976).

South Slavic oral discourse has been born under the influence of the colonial situation that had a decisive effect on the formation of axiological system of epics, while the texts created before the arrival of the Turks were modified due to the elements of another discourse and lexemes taken from the oriental lexical register. Creolization of the cultural units is always supporting the process of colonization, remembered by every member of the collective as his greatest trauma.

The oral formulations such as curses preserve linguistic evidence about the period of colonial trauma that is roughly carved into the collective memory, and a very firm axiological system can be found in a folklore text which is embedded in hatred of the „mighty and cunning" Turks and Islam, as a stable attitude which continues to live in the South Slavic socio-cultural communities and after their withdrawal from the Balkans, because of the resistance of the ideological stance, deep-seated in the phylogenetic memory.

Colonial situation has a detrimental effect on cultural prohibitions and semiotic conventions of the inferior culture, where the victims are usually its most loyal guards - religious codes, sacred places and signs, because of the facts that the destructive power of the colonial dialogue is mainly focused on their degradation. Colonial semiotic activity is focused on the destruction of the semiotic potential of the inferior culture, especially its sacral sphere, while in the colonial communication the politeness strategies don't exist, and an aggressive logic of directives has been introduced, sent by the superior culture to the inferior one.

The image of the Ottoman Empire as a mighty colonial force which for centuries had been imposed on the colonies in the Balkans, their religion, language and culture, where one can recognize the basic colonial ideologeme, concretized in a bid of the superior culture that strives to modify other cultures and subordinate them, constantly accompanied by various struggles between different discourses for domination was created in the South Slavic (post)colonial discourse, where Kosovo plays the main role. In this struggle, the Muslim oral literature made a strong impact on the Christian folk discourse by means of bringing the oriental motifs and vocabulary in the literature. This process of creolisation affects all codes and texts within the colonized cultural space by modifying the culture as a whole, which results in the fact that the South Slavic textuality has been significantly marked by the explicite signs of colonial Alterity. There are also many signs of Austrian and Hungarian colonial aspirations, specially in western part of Balkans, that are reflected in literature and textuality as well, but those cultures are Christian, so there is no such a sharp collision as with the Turkish one.

The communication established between the colonial force and colonized culture always includes the modification of cultural codes as a necessary consequence of the 
colonial dialogue. There are always numerous disorders or deviations in every communicational interaction, whose presence disrupts the process of conveying a message. For centuries, the major disturbing factor in Balkans was a colonial situation, which imposes numerous disense speech acts as the primary regulators of the interaction. Thus, the culture of the colonized and the colonizer's are treated as interlocutors in a colonial dialogue. A good strategy of linguistic interaction is a very important element of any communication, including the colonial one, as speakers, depending on the interactional goal, elect certain speech acts that will help them achieve this goal. However, the colonial situation imposes very aggressive aims, harmonized with an interaction strategy that focused on obedience to a particular submitted culture and maintenance of its inferiority, so the communication has to rely on various disense forms and speech acts, such as: judgment (verdictives), commands (exercitives) and comissives. At the same time, it is necessary to bear in mind the illocutionary power of speech acts, and perlocutionary effect they may have on the respondents and thus the realization of the goal, so that the communication strategy of the colonial force is always focused on disens (non-cooperativeness): "On the contrary, disensed situations are characterized by both or only one party to insist on their demands, which are, sometimes, inconsistent with the general objectives of communication." (Ivanetić 1995: 74)

The external messages, sent in the colonial situation, are received violently which leads to a significant deformation of the channel Me-The Addressee (Lotman 2004), while the channel Me-Me, due to the endangered cultural cohesion, increases its activity. Domicile culture is forced to intensify the autocommunication which includes resistance to messages that come from outside, from a channel Me-The Addressee, because its main purpose becomes the preservation of cultural identity, which can seriously jeopardize the strong and violent invasions of others' codes and texts. Therefore, the activity of this channel becomes reduced, through which only the obligatory messages can be recieved, and the result of this type of communication is creolisation of the domicile culture, which is something that never comes voluntarily, although the mechanisms of coercion are sometimes hidden and subtle. The domicile culture, forced to be autistic, turns to an intensive mythologisation and the cult of the past as a repository of identity information, which leads to an increased reproduction of the process of self-acknowledgement and egocentric speech. This is accompanied by reduced activity of the channel Me-Addressee, shown as refusing the texts written by others and the language of the colonizers. This defensive process leads to strengthening of oral codes and activating cultural and mnemonic mechanisms of the era of pre-literacy, because common people in Ottoman Empire, so called raja, usually don't write and read, and oral texts are used for storing the collective truth and facts relevant to the survival of vulnerable socio-cultural community.

So, in the cruel conditions of colonization the domestic cultural space is isolated as well, and, at the same time, protected against dialogue with the foreign texts just for the sake of survival, but that process will, eventually, produce a conservative, autistic 
and self-contained culture, showing much less dynamism than required by the needs of the human society. The endangered culture activates all available defences, and as a collective always keeps itself and identity via texts, while intertextuality appears as a mnemonic and defense mechanism, whereby self-awareness, memory of the heroic being and the superiority of their own culture, are stored in the canonical texts, as in a kind of guardians of collective identity.

Christians in the Balkans have preserved their language and culture through the process of self-communication, which is crucial in maintaining the identity of the colonized cultures: "It is necessary to distinguish between two types of autocomminication: the one containnig mnemonic function and the one without it." (Lotman 2004: 39). So, in the opressed culture, an intense communication on a channel Me-Me, with a strong mnemonic function, has been developed as one of its defense strategies, while a temporal boundary that separates the two substructures has been created in the narration of identity - the domicile culture from the period before, and after colonization and creolisation because so sharp and aggressive intrusion of other people's cultural codes and cognitive patterns inevitably leads to a serious revision of codes of conduct and to modifications of identity patterns.

The inverting the real balance of power in the artistic text is one of the favorite strategies of the epic poet, who in this way kept for eternity memory of his own supremacy, though fictional, but very powerful in terms of social semiotics. Therefore, at the very time of endangerment of a social community the authors launch the texts in which is stored the memory of a fictional or real superiority of the collective and successful battle with someone else's culture because such texts function as a specific defense mechanisms of a culture.

Saidian connection between literature, geography, and imperialism (Said, 1978) is truly exposed in numerous literary works in Soth Slavic semiosphere or cultural space, since they are organized as an artistic transposition of the colonial situation, in which the authors present the turmoil of the semiotic energy, released during the collision of two cultures, different religious codes, which is why their antagonism is even deeper and communication more aggressive. The splitting of the space on the Christian and Islamic substructure is evident in South Slavic cultures, in social practise and literary works as well, especially in Bosnia and Herzegovina after the war.

\section{Conclusions}

It can be concluded that in this very strange mythological way Kosovo keeps for eternity the memory of Christian supremacy, though fictional, but very powerful in terms of social semiotics. Understanding of the alterity and intercultural dialog should be based on recognition of this specific mythological aspect of history, human existence and thinking, social practice and also politics. So, the political solutions that are going to be offered to Balkans issue should rely on that mythological and sacred 
semiotic material, because the religious and identity map of Balkans is very complicated and it's based on numerous traumas, which shouldn't be provoked any more.

Recent political events indicate that there are layers and layers of aggressiveness in Balkans, which are produced in this boiling kettle of different cultural and religious codes, whose evil is always liberated in politicly tense situations and military operations. So, Kosovo, as a very powerful mythological and political phenomenon, in the aggressive discourse of nationalists may function as such a trigger that could lead Balkans to another war situation.

\section{References}

[1] Bahtin, Mihail (1989). O romanu. Beograd. Nolit.

[2] Bećković, Matija (2018). Najskuplja srpska reč. Prizren. Eparhija raškoprizrenska.

[3] Čajkanović, Velimir (1973). Mit i religija u Srba. Sabrana dela. Beograd. Srpska književna zadruga.

[4] Čolović, Ivan (2016). Smrt na Kosovu polju. Istorija kosovskog mita. Beograd. Biblioteka XX vek.

[5] Ćirković, Sima (1990). Kosovska bitka kao istorijski problem. Zbornik radova, 11, 109-118. Beograd. Istorijski institut SANU.

[6] Dejzings, Ger (2005). Religija i identitet na Kosovu. Beograd. Biblioteka XX vek.

[7] Di Lelio, Ana (2010). Bitka na Kosovu u albanskom epu. Beograd. Biblioteka XX vek.

[8] Đorđević, Tihomir (1984). Naš narodni život IV. Beograd. Prosveta.

[9] Hol, Edvard (1976). Nemi jezik. Beograd. BIGZ.

[10] Ivanetić, N. (1995). Govorni činovi. Zagreb. Institut za linvistiku na Filozofskom fakultetu.

[11] Lotman, Jurij M. (2004). Semiosfera. Prevod s ruskog Veselka Santini. Novi Sad. Svetovi.

[12] Oraić Tolić, Dubravka (1990). Teorija citatnosti. Zagreb. Grafički zavod Hrvatske.

[13] Popović, Miodrag (2007). Vidovdan i časni krst. Ogled iz književne arheologije. Biblioteka XX vek. Beograd.

[14] Said, Edward W. (1978). Orientalism. New York. Pantheon Books.

[15] Velimirović, Nikolaj (2013). Kosovo i Vidovdan. Beograd: Podgorica. 


\section{Štampar Makarije: Oktoih.}

